\title{
Opportunities or Challenges? Building Student Social Character through WhatsApp-Based Project Citizen in Disruptive Era
}

\author{
Tetep $^{1}$, Jamilah ${ }^{2}$, Endang Dimyati ${ }^{3}$, Odang Hermanto ${ }^{4}$ \\ \{tetep@institutpendidikan.ac.id ${ }^{1}$, jamilah@institutpendidikan.ac.id ${ }^{2}$, \\ endangdimyati@institutpendidikan.ac.id $\left.{ }^{3}\right\}$ \\ Institut Pendidikan Indonesia, Jl. Terusan Pahlawan No.83, Garut 44151 ${ }^{1234}$
}

\begin{abstract}
The disruptive era is marked by the cloud wars happening in the cyberspace. This disruptive era provides both opportunities and challenges to education. The WhatsApp-based Project Citizen model aims at developing student social character required to deal with the opportunities and challenges of the disruptive era. This study was conducted on social science students in Indonesia. The implementation of WhatsAppbased Project Citizen allows students to actively, critically, creatively, innovatively, and cooperatively participate in democracy and tolerance building. The results of this study show that WhatsApp-based Project Citizen model improved the openness of classroom climate and foster a cooperative responsibility and democratic values in students. This implies that the wise use of social media can help build social intelligence in the young generation of the nation.
\end{abstract}

Keywords: social character, project citizen, disruptive era.

\section{Introduction}

WhatsApp social media is one of the many social media used by people throughout the world. In Indonesia WhatsApp users reach 35.8 million users and become a media with a high rating, comScore reports show the following data [1].

Table 1.1 Whatsapp User in Indonesia

\begin{tabular}{|c|c|c|c|}
\hline \multicolumn{4}{|c|}{$\begin{array}{l}\text { Top } 10 \text { Apps from Mobile Devices in Indonesia } \\
\text { January } 2017 \\
\text { Total Indonesia - Age 18+. Mobile App only } \\
\text { Source: comScore Mobile Metrix }\end{array}$} \\
\hline \multirow[t]{2}{*}{ Rank } & \multirow[t]{2}{*}{ App } & \multicolumn{2}{|l|}{ Total Mobile } \\
\hline & & Total Unique Visitors (0oo) & \% Reach \\
\hline & Total Internet: Total Audience (Mobile App only) & 46,130 & 100.0 \\
\hline 1 & Google Play & 44,292 & 96.0 \\
\hline 2 & WhatsApp Messenger & 35,799 & 77.6 \\
\hline 3 & YouTube & 35,627 & 77.2 \\
\hline 4 & BвM & 34,748 & 75.3 \\
\hline 5 & Google Search & 30,442 & 66.0 \\
\hline 6 & Gmail & 28,584 & 62.0 \\
\hline 7 & Line & 27,613 & 59.9 \\
\hline 8 & Instagram & 23,876 & 51.8 \\
\hline 9 & Facebook & 22,268 & 48.3 \\
\hline 10 & Google Maps & 20,865 & 45.2 \\
\hline
\end{tabular}


The data shows that WhatsApp can be an effective and efficient medium in influencing people's thoughts, behaviour and actions from the information they obtain. The love of WhatsApp media is also increasingly used among millennials, such as students. Gasaymeh (2017) in his research explained that students use a lot of WhatsApp for personal gain, while for the sake of education there is still limited scope, if used in education WhatsApp will provide convenience, fun and useful.

The citizen model project is a learning philosophy that teaches how students are prepared to become good citizens. The community policy and provide input on public policy in their environment (Atherton, 2000; Vont, 2000). The WhatsApp Based Citizen Project is an integration of the use of WhatsApp social media in social studies learning to build the social character values of students. Social character is an effort to form human forces in a particular society to function the community sustainably towards a democratic and humane society (Fromm, 1995). Indicators of social character that can be developed at the school or campus include cooperation, tolerance, respect and respect for others, caring or solidarity (Tetep, 2014). These social character values can be developed in WhatsApp-based citizen projects. Citizen project values consist of civic knowledge, civic skills and civic disposition (Atherton, 2000; Vontz, 2000).

The formulation of this study will answer the frequency of WhatsApp use by students at the Indonesian Educational Institute, the use of WhatsApp to support the student learning process with the value of project citizens at the Indonesian Education Institute, and the effectiveness of using WhatsApp media in instilling student social character values with project citizens. WhatsApp media integration with the value of social characters and citizen projects hopes that the increasing number of WhatsApp users among students will further enhance the intelligence and skills of students in their utilization so that they can transmit the value of the social character to citizen projects in creating good citizens.

\section{Method}

The research method uses a quantitative approach; data were collected by using a questionnaire to see the frequency of utilization of WhatsApp, both personal use and utilization for learning. To see the effectiveness of the use of questionnaires taken from questionnaire data which is the student's answer to the use of WhatsApp with project citizens and social character values that are inserted in each statement questionnaire. The questionnaire instrument developed was a Likert attitude scale. Sixty-five students became the sample in this study which was taken homogeneously based on the class in the Social Studies Education study program, namely classes A and B. The data were obtained and analyzed using descriptive statistics.

\section{Result and Discussion}

a. The frequency of WhatsApp usage by students of the Social Studies Education Program at the Indonesian Institute of Education. 


\begin{tabular}{|c|c|c|c|c|c|}
\hline \multirow{2}{*}{ No } & \multirow{2}{*}{ Used } & \multicolumn{2}{|c|}{ Sex } & \multirow{2}{*}{ Amn } & \multirow{2}{*}{$\%$} \\
\hline & & M & $\mathrm{F}$ & & \\
\hline 1 & Everyday & 21 & 39 & 65 & 91,6 \\
\hline 2 & Sometimes & 2 & 3 & 5 & 8,4 \\
\hline \multirow[t]{2}{*}{3} & Never & 0 & 0 & 0 & 0 \\
\hline & Amount & 22 & 38 & 60 & 100 \\
\hline
\end{tabular}

Based on the table above, it can be explained that the frequency of using Whatsapp media by students in Social Studies education study programs from 65 students with 21 men and 395 women, $91.6 \%$ or 65 people from the number of respondents using Whatsapp facilities every day while $8.4 \%$ or only 5 people who use WhatsApp facilities at any time consisting of 2 male students and 3 female students. Whatsapp is currently a popular social media that widely used. Statista (2017) explains that there are 1.2 billion actives using WhatsApp every month. Whatsapp is a media-based smartphone application that allows users to exchange information with a variety of media both text, images, videos and audio messages (Chruch \& de Oliveira, 2013; Sahu, 2014, Gasaymeh, 2017). Tang \& Hew (2017) explains that WhatsApp is a free, easy to use, fast, convenient, personal mode of communication. And it's easy to form groups or private communication. At the Indonesian Education Institute, the frequency of using WhatsApp media by students done every day. Research Devi \& Tevera (2014) found that WhatsApp is one of the most popular media used by students.

b. How is the integration of WhatsApp utilization in supporting the student learning process with the value of a project citizen at the Indonesian Education Institute?

Habit Questionnaire Data Using WhatsApp Media without charged Project Citizen and Social Character Values

\begin{tabular}{|c|c|c|c|c|c|c|c|}
\hline \multirow{2}{*}{ No } & \multirow[t]{2}{*}{ The habit of Using WhatsApp } & \multicolumn{2}{|c|}{ Every time } & \multicolumn{2}{|c|}{ sometimes } & \multicolumn{2}{|c|}{ never } \\
\hline & & $\mathrm{Am}$ & $\%$ & Am & $\%$ & $\mathrm{Am}$ & $\%$ \\
\hline 1 & Personal Chatting & 65 & 100,00 & & 100 & & 0,00 \\
\hline 2 & Communication in Group & 10 & 15,38 & 55 & 84,62 & & 0,00 \\
\hline 3 & Ask the Matter to lecture & 5 & 7,69 & 5 & 7,69 & 55 & 84,62 \\
\hline 4 & Sharing learning idea & 2 & 3,08 & 5 & 7,69 & 58 & 89,23 \\
\hline 5 & Sharing Matter area by friend & 15 & 23,08 & 15 & 23,08 & 35 & 53,85 \\
\hline 6 & Giving feedback of matter & 7 & 10,77 & 10 & 15,38 & 48 & 73,85 \\
\hline 7 & $\begin{array}{l}\text { Helping difficulties study of the } \\
\text { friend }\end{array}$ & 3 & 4,62 & 15 & 23,08 & 47 & 72,31 \\
\hline 8 & Keep the Balance of Information & 5 & 7,69 & 7 & 10,77 & 53 & 81,54 \\
\hline 9 & Keep the Social ethics & 12 & 18,46 & 35 & 53,85 & 18 & 27,69 \\
\hline 10 & Be tolerance by inform and share & 10 & 15,38 & 25 & 38,46 & 30 & 46,15 \\
\hline 11 & Keep Democratic in the Diversity & 15 & 23,08 & 25 & 38,46 & 25 & 38,46 \\
\hline 12 & Help solve learning problem & 3 & 4,62 & 15 & 23,08 & 47 & 72,31 \\
\hline
\end{tabular}




\begin{tabular}{lllllllll}
\hline 13 & $\begin{array}{l}\text { Keep togetherness and not } \\
\text { provocative }\end{array}$ & 5 & 7,69 & 45 & 69,23 & 15 & 23,08 \\
\hline 14 & Respect the differencies & 12 & 18,46 & 35 & 53,85 & 18 & 27,69 \\
\hline 15 & Wise in Giving information & 5 & 7,69 & 45 & 69,23 & 15 & 23,08 \\
\hline
\end{tabular}

From the table above, it can be explain that the habits of students of social studies education programs using WhatsApp media without charged citizen projects and social character values of $100 \%$ WhatsApp used for personal chat purposes, the data is only a little WhatsApp media is used for their educational purposes, even on item no. 4 there were $89 \%$ of students who never shared their learning, and $84.62 \%$ never asked the lecturer about the learning material he delivered. While communication conducted with groups is sometimes carried out, there are 55 students or $84.62 \%$ communicating in groups. Whatsapp is still limited in its use to support learning that has the value of citizen projects and social character values. The use of WhatsApp by students for educational purposes is still limited and usually related to research studies only (Yeboah \& Ewur, 2014, Gasaymeh, 2017). Whatsapp has a good impact on improving student learning achievement (Amry, 2014). If WhatsApp contains project citizens are used well, then it will help support education for students.

Habit Questionnaire Data Using WhatsApp Media with integration with Project Citizen and Social Character Values

\begin{tabular}{|c|c|c|c|c|c|c|c|}
\hline \multirow{2}{*}{ No } & \multirow[t]{2}{*}{ Habit of Using WhatsApp } & \multicolumn{2}{|c|}{ Everytimes } & \multicolumn{2}{|c|}{ sometimes } & \multicolumn{2}{|c|}{ never } \\
\hline & & Am & $\%$ & $\mathrm{Am}$ & $\%$ & $\mathrm{Am}$ & $\%$ \\
\hline 1 & Personal Chatting & 65 & 100,00 & & & & \\
\hline 2 & Communication in Group & 45 & 69,23 & 20 & 30,77 & & \\
\hline 3 & Ask the Matter to lecture & 35 & 53,85 & 25 & 38,46 & 5 & 7,69 \\
\hline 4 & Sharing learning idea & 30 & 46,15 & 15 & 23,08 & 20 & 30,77 \\
\hline 5 & Sharing Matter area by friend & 45 & 69,23 & 20 & 30,77 & 0 & 0,00 \\
\hline 6 & Giving feedback of matter & 17 & 26,15 & 40 & 61,54 & 5 & 7,69 \\
\hline 7 & $\begin{array}{l}\text { Helping difficulties study of the } \\
\text { friend }\end{array}$ & 25 & 38,46 & 25 & 38,46 & 15 & 23,08 \\
\hline 8 & Keep the Balance of Information & 32 & 49,23 & 25 & 38,46 & 5 & 7,69 \\
\hline 9 & Keep the Social ethics & 37 & 56,92 & 23 & 35,38 & 5 & 7,69 \\
\hline 10 & Be tolerance by inform and share & 43 & 66,15 & 20 & 30,77 & 2 & 3,08 \\
\hline 11 & Keep Democratic in the Diversity & 38 & 58,46 & 22 & 33,85 & 5 & 7,69 \\
\hline 12 & Help solve learning problem & 24 & 36,92 & 37 & 56,92 & 4 & 6,15 \\
\hline 13 & $\begin{array}{l}\text { Keep togetherness and not } \\
\text { provocative }\end{array}$ & 32 & 49,23 & 30 & 46,15 & 3 & 4,62 \\
\hline 14 & Respect the differencies & 55 & 84,62 & 10 & 15,38 & 0 & 0,00 \\
\hline 15 & Wise in Giving information & 42 & 64,62 & 22 & 33,85 & 1 & 1,54 \\
\hline
\end{tabular}

There is a change in the habit of using WhatsApp after citizen project integration and the value of social character even though personal chat is still $100 \%$ the object of using WhatsApp media. There are significant improvements such as respect the differences from $18.4 \%$ to $84.62 \%$, which means that the more integrated the citizen project content and the value of social character in students, the use of WhatsApp media provides benefits in providing information 
and becoming an effective medium for instilling the value of social character on students. There is also a significant increase, for example, item wise giving information from $7.6 \%$ to $64.62 \%$, meaning that there is a significant increase in student understanding if the contents of citizen projects and social character values are integrated into students in utilizing WhatsApp facilities. Any information provided will be of value to the cultivation of values of social character such as tolerance, democracy, wisdom and solidarity.

c. How effective is the use of WhatsApp media in instilling student social character values with project citizens?

\begin{tabular}{l|l|l|l|l}
\hline \multicolumn{5}{|c}{ Correlations } \\
\hline \multirow{2}{*}{ Spearman's rho } & \multirow{2}{*}{ WPC } & Correlation Coefficient & 1.000 & $.832^{*}$ \\
\cline { 3 - 5 } & & Sig. (2-tailed) &. & .001 \\
\cline { 3 - 5 } & $\mathrm{N}$ & 65 & 65 \\
\cline { 3 - 5 } & \multirow{2}{*}{ SC } & Correlation Coefficient & $.832^{*}$ & 1.000 \\
\cline { 3 - 5 } & & Sig. (2-tailed) & .001 &. \\
\hline & $\mathrm{N}$ & 65 & 65 \\
\hline
\end{tabular}

The results showed that there was a significant correlation between WhatsApp citizen project use towards the formation of student social character values, around $83.2 \%$, meaning it was assumed that the influence was strong. Integration of citizen projects in learning has implications for the climate of the democratic class (Adha et al. 2018). A good class climate can encourage the formation of social character values in students (Tetep, 2015). Integrating citizen projects in learning involves students to work together, help each other, build solidarity and discuss problems solving (Atherton \& Vontz, 2000; Ristina 2009). The use of Whatsapp Media influences the dissemination of learning information (Pangestika, 2018). In this study shows that the use of WhatsApp media with this citizen project has a strong influence in instilling the formation of student social character values if it is positively used.

\section{Conclusion}

The use of WhatsApp media from personal use can be used to support the process of student education and learning. The limited use of WhatsApp media in learning so far because WhatsApp has been widely used for personal information only and the limited understanding of users including lecturers or teachers to integrate it into learning. Whatsapp with project citizens is the integration of the values of the project citizen's goals in instilling social character values such as democracy, solidarity, togetherness, tolerance and caring can be done by utilizing WhatsApp group and personal facilities by sharing good and honest information. 


\section{Reference}

[1] Adha, M.M, Yanzi, H, Nurmalisa, Y. (2018). The Improvement of Student Intelectual and Participatory Skill Through Project Citizen Model in Civic Education Classroom. International Journal Pedagogy Of Social Studies, 3 (1), 2018, 39-50 . Bandung : UPI.

[2] Gon, Sonia; Rawekar, Alka. (2017). Effectivity of E-Learning through Whatsapp as a Teaching Learning Tool. MVP Journal of Medical Sciences, Vol 4(1), 19-25, January-June 2017.

[3] Amry, Aicha Blehch. (2014). The Impact Of Whatsapp Mobile Social Learning On The Achievement And Attitudes Of Female Students Compared With Face To Face Learning In The Classroom. European Scientific Journal August 2014 edition vol.10, No.22 ISSN: 1857 - 7881 (Print) e - ISSN 1857- 7431

[4] Prajana, Andika. (2017). Pemanfaatan Aplikasi Whatsapp Dalam Media Pembelajaran Di UIN Ar-Raniry Banda Aceh. Jurnal Pendidikan Teknologi Informasi Volume 1, Nomor 2, Oktober 2017, 122-133

[5] Gasaymeh, AM. (2017). University Students' use of Whatsapp and their Perceptions Regarding its Possible Integration into their Education. Global Journal of Computer Science and Technology: G Interdisciplinary Volume 17 Issue 1 Version 1.0 Year 2017.

[6] Yeboah, J., \& Ewur, G. D. (2014). The impact of whatsApp messenger usage on students performance in Tertiary Institutions in Ghana. Journal of Education and practice, 5(6), 157-164.

[7] Tang, Y., \& Hew, K. F. (2017). Is mobile instant messaging (MIM) useful in education? Examining its technological, pedagogical, and social affordances. Educational Research Review. Retrieved June 8, 2017, from http://www.sciencedirect.com/science/article/pii/S0747563216305039

[8] Sahu, S. (2014). An Analysis of WhatsApp Forensics in Android Smartphones. International Journal of Engineering Research, 3(5), 349-350.

[9] Devi, T. S., \& Tevera, S. (2014). Use of social networking site in the University of Swaziland by the health science students: A Case study. Jounal of Information Management, 1(1), 19-26.

[10] Church, K., \& de Oliveira, R. (2013). What's up with whatsapp?: comparing mobile instant messaging behaviors with traditional SMS. In Proceedings of the 15th international conference on Human-computer interaction with mobile devices and services (pp. 352-361). ACM.

[11] Pangestika, NL., (2018). Pengaruh Pemanfaatan Media Sosial Whatsapp Terhadap Penyebaran Informasi Pembelajaran Di Sma Negeri 5 Depok. Skripsi,. Jakarta : UIN Syarif Hidayatullah.

[12] Fromm. Erich. (1942), Character and the Social Process .Appendix to Fear of Freedom, Routledge, 1942;

[13] Funk, Rainer (1998) Erich Fromm's Concept of Social Character, Tuebingen Social Thought \& Research, Vol. 21, No. 1-2

[14] https://id.techinasia.com/comscore-whatsapp-adalah-aplikasi-terpopuler-di-indonesia

[15] Tetep. (2014). Optimalisasi Peran Iklim Sekolah bagi pembentukan karakter sosial Peserta didik. Bandung : Pascasarjana Pendidikan IPS UPI. 